\title{
牛の子宮内膜炎の治療
}

\author{
常 包正 (家畜衛生試験場北陸支場)
}

牛の子宮内膜炎の治療は，抗生物質の登場を契機とす る新しい化学療法に関する研究にともない, 多くの業績 がみられるに至つたことは誠に喜ばしいことである。

昨年度の本研究会で, 子宮洗滌の要否, ホルモン剤の 添加特よび薬用量等について論議がかわされた。この点 については1956年10月からすでに研究を行なつていたの であるが，さらに1957年 7 月から再検討を行つた両者に ついて報告する。

\section{I. 試験材料及び試験方法}

1. 材料牛：1956年10月から1957年12月までの間に, 新潟及び長野県下で乳牛の栄養障害調查時, 臨床検査で 子宮内膜炎と診定したホルスタイン種及び同系種 128 頭 である。その区分はカタール性子宮内膜炎 121 頭，膿漏 性子宮内膜炎 7 頭で, 蓄膿症は 1 頭もなかつた。

2. 薬 物：第一次試験に用いた薬物は武田薬品工業 $\mathrm{KK}$ で試作のマストール 3 種と日本全薬工業 $\mathrm{KK}$ 製のペ ニストマイシン内膜グル 1 種計 4 種である。

各薬物の処方は次の通りである。

$$
\begin{aligned}
& \text { （1）マストールu（Mu と略） } \\
& \text { プロカインペニシリン } \mathrm{G} \\
& \text { 硫酸ジヒドロストレプトマイシン } \\
& \text { 硫酸フラジオマイシン } \\
& \text { サルファチアゾール } \\
& \text { サルフアダイアジン } \\
& \text { 300, } 000 \mathrm{U} \text {. } \\
& 150 \mathrm{mg} \text { (力価) } \\
& 300 \mathrm{mg} \text { (力価) } \\
& 600 \mathrm{mg} \\
& 300 \mathrm{mg} \\
& 80 \mathrm{cc}
\end{aligned}
$$

第二次試験では武田薬品工業 KK Kで試作のマストール

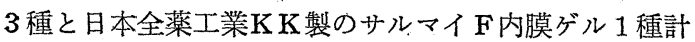
4 種を用いた。
各薬物の処方は次の通りである。

（1） マストール $\mathrm{u}_{20}$ ( $\mathrm{Mu}_{20}$ と略)

$$
\begin{aligned}
& \text { プロカインペニシリンG } \\
& \text { 硫酸ジヒドロストレプトマイシン } \\
& \text { 硫酸フラジオマイシン } \\
& \text { サルファキアゾール } \\
& \text { サルフアダイアジン }
\end{aligned}
$$

植物油

$400,000 \mathrm{U}$

$200 \mathrm{mg}$ (力価) $600 \mathrm{mg}$ (力価)

$1,200 \mathrm{mg}$

$600 \mathrm{mg}$

$20 \mathrm{cc}$

（2）マストール $\mathrm{u}_{50}\left(\mathrm{Mu}_{50}\right.$ と略)

上記処方の植物油 $20 \mathrm{cc}$ を $50 \mathrm{cc}$ としたるの。

（3）マストール uH3 ( $\mathrm{MuH}_{\mathrm{H} 3}$ と略)

マストール U オイベスチン $0.5 \mathrm{mg} \quad$ プロゲステロン $10 \mathrm{mg}$

（4）サルマイ F内膜吕（ SF と略）

プロカインペニシリン G 400, $000 \mathrm{U}$.

硫酸ジヒドロストレプトマイシン サルフアチアゾール $400 \mathrm{mg}$ (力価)

サルフアメラジン $300 \mathrm{mg}$ サルフアダイアジン $300 \mathrm{mg}$

ニトロフラゾーン $300 \mathrm{mg}$

硫酸コバルト $100 \mathrm{mg}$

鉱 物 油 $5 \mathrm{mg}$ $70 \mathrm{cc}$
3. 試験方法: 第一次試験は洗滌の要否及びホルモン 剤添加の検討を行う目的で, 従前通り洗滌を行なつた後 薬物を注入する方法 (Mu 及び PSM を応用) と全く洗

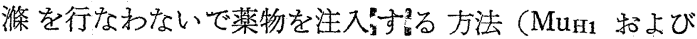
$\mathrm{Mu}_{\mathrm{H} 2}$ を応用）を実施した。

第二次試験はホルモン剤添加と薬用量についての検討 を主体とし，洗滌をせず薬物の注入だけを実施した。

両試験とも試験牛に各薬物を無作為的に応用し, 卵巣 疾患气の他の生殖器疾患を併発しているものに対しては, それぞれ併せ治療を行なつた。治療後14日以降汇再検査 を行なつて治癒判定を行ない，治癒と判定したものに対 しては種付を実施し，さらに妊否を確認した。

\section{II. 試験成績}

、第一次試験では，子宮洗滌の Mu 特上び PSMの完全 癒率は夫々 88.89 および $100 \%$ でめつた。非洗滌群の MuH1 怙よび $\mathrm{MuH}_{2}$ の完全治癒率はともに $83.33 \%$ で 全平均では $88.24 \%$ であつた (第1表)。 
1958. 7 月

第 1 表 第一次治療試験成績 (1956. 10～1957．6)

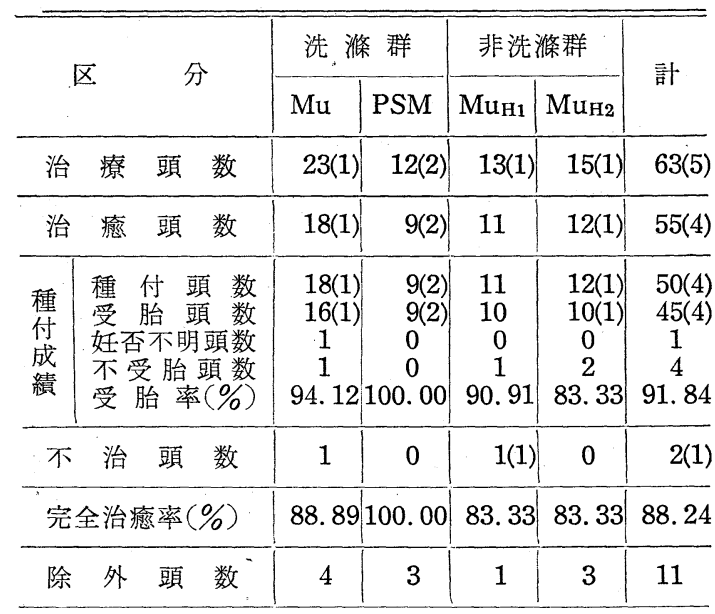

註：（1）（）内数字は膿漏性または多量の分泌性子 宮内膜炎を示し，いずれも内数とする。（2）完 全治癒率とは治療頭数一(妊否不明頭数十除外頭数) $\times 100$ である。（3）除外頭数は併発症が不治のた め除外したものである。（4）本試験成績はいずれ も 1 回治療によるものである。

各註は第 2 表にも適用す。

第二次試験では $\mathrm{Mu}_{20}, \mathrm{Mu}_{50}, \mathrm{MuH3}$ 及び $\mathrm{SF}$ の完全 治癒率は夫々 $66.67,75.00,75,00$ 及び $76.92 \%$ であ つて，全平均では $73.58 \%$ であつた（第 2 表)。

この両試験の完全治癒率をみると，第一次が第二次よ り平均で $14.66 \%$ 高く，また洗滌群と第一次第二次の非 洗滌群では前者が後者より $14.67 \%$ 良好な成績を示した。 しかし第一次及び第二次試験，各応用薬物相互間，洗滌 の有無，ホルモン剤添加の有無等について統計処理を行 なつたが，いずれも有意差を認めなかつた。

\section{III. 総 括}

本試験の成績を総合して考察すると，

（1）各試験区の完全治癒率では相違が認められるが, 統計処理の結果では有意差が認められない。従つてホル モン添加の意義は見いだせなく, 薬用量も従来より少く てよいようであり，洗滌も(2)で述べるようなるのを除 いては行なわなくてもよいのではないかと考える。

（2）膿漏性又は多量の分泌性の臨床症状を呈するも のが，洗滌を行なつたものの中に 3 頭，洗滌しなかつた ものの中に 6 頭計 9 頭女つた。洗滌を行なつたものはす べて1回治療で治癒受胎したが，洗眇をしなかつたもの では 1 回治療で 1 頭が治癒受胎しただけで残りの 5 頭は
家畜繁殖誌 4 巻 1 号

第 2 表 第二次浩療試験成績（1957. 7～12）

\begin{tabular}{|c|c|c|c|c|c|c|}
\hline \multicolumn{2}{|c|}{ 区 分 } & \multirow{2}{*}{$\frac{\mathrm{Mu}_{20}}{15(1)}$} & \multirow{2}{*}{$\frac{\mathrm{Mu}_{50}}{16}$} & \multirow{2}{*}{$\frac{\mathrm{MuH}_{3}}{18(2)}$} & \multirow{2}{*}{$\frac{S F}{16(1)}$} & \multirow{2}{*}{$\frac{\text { 計 }}{65(4)}$} \\
\hline 治 & 療 頭 数 & & & & & \\
\hline 治 & 癒 頭 数 & 13 & 12 & 14 & 13 & 52 \\
\hline $\begin{array}{l}\text { 種 } \\
\text { 付 } \\
\text { 成 } \\
\text { 績 }\end{array}$ & $\begin{array}{l}\text { 種付 頭 数 } \\
\text { 受胎 頭 数 } \\
\text { 妊否不明.頭数 } \\
\text { 不受胎頭 数 } \\
\text { 受胎率 }(\%)\end{array}$ & $\begin{array}{c}13 \\
9 * 1 \\
2 \\
2 \\
81.82\end{array}$ & $\begin{array}{c}12 \\
9 \\
1 \\
2 \\
81.82\end{array}$ & $\begin{array}{c}14 \\
12 \\
1 \\
1_{* 1} \\
92.31\end{array}$ & $\begin{array}{c}13 \\
10 \\
2 \\
1 \\
90.91\end{array}$ & $\begin{array}{c}52 \\
40 \\
6 \\
6 \\
86.96\end{array}$ \\
\hline 不 & 治 頭 数 & $1(1)$ & 1 & $3(2)$ & $2(1)$ & $7(4)$ \\
\hline & 企治癒率 (\%) & 66.67 & 75.00 & 75.00 & 76.92 & 73.58 \\
\hline 除 & 外 頭 数 & 1 & 3 & 1 & 1 & 6 \\
\hline
\end{tabular}

注： $\mathrm{Mu}_{20}$ 受胎頭数欄中*1 2 カ月後に 1 頭流産し たるの， $\mathrm{MuH}_{3}$ 不受胎頭欄中の*1 44 回目の種付で 受胎したものでいずれも内数である。

不治であつた。これら不治の 5 頭のうち 4 頭を洗滌後薬 液注入する方法をとつたところ 4 頭共に治癒し， 3 頭が 受胎，1頭は妊否不明である。このよ5な点から上記臨 床所見を呈するものでは洗滌を行なうことが必要である。

（3）薬用量は 20cc でも効果を認めたが，一般性ま た安全性等から $50 \mathrm{cc}$ 位がよいのではないかと考える。

（4）本試験の材料牛は内膜炎だけのものを選ぶこと が困難であつたので，卵巣疾患等の併発したものを含め て実施した関係上，卵巣疾患が不治のため17頭を除外し た。また臨床上では一応治癒と認めたが不受胎のものが 10頭 $(10.88 \%)$ あつた。これらのことから牛の子宮内 膜炎の原因が細菌性ばかりでなく，内分泌，栄養その他 多様性であることが考えられるので, 今後の問題として 総合的な診断に基づいて，総合的な治療を実施すること の必要性が痛感せられる。

（5）牛の子宮内膜炎汇しても，その他の繁殖障害に しても，その成績の出し方が同一でないことは遺憾と考 えるもので, 私は受胎成績は治療後 120 日以内, 種付 3 回までとし，その後のものは不受胎として集計し，完全 治癒率によつて表示することを提唱する。

終りに臨み終始御指導ならびに御校閲を賜つた吉田支 場長に謝意を表すると共に本試験に御協力下さつた新潟, 長野画県畜産課衛生係員, 新潟県北蒲原, 西蒲原, 北魚 沼各家畜保健所所員, 長野県南信酪農業協同組合和よび 協同乳業株式会社各獣医師職員ならびに薬物を御供与下 さつた武田薬品工業株式会社永よび日本全薬株式会社に 深謝する。 